\title{
Impacts of low pH and low salinity induced by acid rain on the photosynthetic activity of green tidal alga Ulva prolifera
}

\author{
Z.F. ZHAO ${ }^{*, * * * * *}$, Z.Y. LIU ${ }^{*, * *}$, S. QIN",*** X.H. WANG ${ }^{* *, * * *, \#, ~ W . L . ~ S O N G ~}{ }^{*, * *}$, K. LIU ${ }^{*, * *}$,

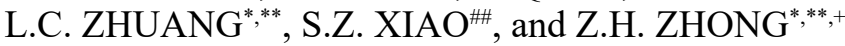

Key Laboratory of Coastal Biology and Bioresource Utilization, Yantai Institute of Coastal Zone Research, Chinese Academy of Sciences, 264003 Yantai, Shangdong, China* Center for Ocean Mega-Science, Chinese Academy of Sciences, 266071 Qingdao, Shangdong, China** University of Chinese Academy of Sciences, 101407 Beijing, China ${ }^{* * *}$

Key Laboratory of Coastal Zone Environmental Process and Ecological Remediation, Yantai Institute of Coastal Zone Research, Chinese Academy of Sciences, 264003 Yantai, Shangdong, China ${ }^{*}$ Changdao Dongyuan Seafood Co. Ltd., 265800 Yantai, Shangdong, China"\#t

\begin{abstract}
Acid rain is a serious environmental problem and has obvious impacts on the growth, reproduction, and photosynthesis of terrestrial plants. Ulva prolifera, a main blooming species of green tides, was studied on its physiological response to acid rain. The photosynthetic parameters were determined under different conditions (salinity: 1, 10, 30\%o; $\mathrm{pH}: 3.0$, $3.5,4.5$; duration: $0.5,1.0,2.0 \mathrm{~h}$ ) followed by $24-\mathrm{h}$ recovering under natural conditions. Results showed 1-h treatment with $\mathrm{pH} 3.5$ caused $50-70 \%$ reduction in the maximal quantum yield of PSII photochemistry $\left(\mathrm{F}_{\mathrm{v}} / \mathrm{F}_{\mathrm{m}}\right)$ and effective quantum yield of PSII photochemistry $\left(\Phi_{\text {PSII }}\right)$ at normal salinity but when the low $\mathrm{pH}$ was combined with a salinity of $10 \%$ or lower, PSII activity was almost completely inhibited. Moreover, the low salinity (1\%o and $10 \%$ ) reduced the degree of photoprotection under low $\mathrm{pH}$ (3.5) conditions. Finally, we speculated if the $\mathrm{pH}$ of acid rain $\leq 3.5$, with $1 \%$ salinity and 2-h rainfall time, the amount of $U$. prolifera and the scale of green tides would decrease.
\end{abstract}

Keywords: acid rain; chlorophyll fluorescence; nonphotochemical quenching; photosynthetic activity; Ulva prolifera.

\section{Introduction}

Acid rain, with $\mathrm{pH}$ values lower than 5.6, is one of the serious examples of regional air pollution (Charlson and Rodhe 1982). It is caused mainly by $\mathrm{SO}_{2}$ dissolution and nitrogen oxides in the atmosphere (Shukla et al. 2013). Next to Western Europe and North America, China has become the third largest acid rain region in the world, especially in the southern and southwestern parts of China (Larssen et al. 2006). In China, Zhejiang Province was

\section{Highlights}

- The activity of Ulva prolifera exposed to different $\mathrm{pH}$ and salinity changed differently

- The low salinity could reduce NPQ of $U$. prolifera under low $\mathrm{pH}$ condition

- The study provided a reference for predicting the scale of green tides by acid rain
Received 20 March 2021

Accepted 25 June 2021

Published online 22 July 2021

${ }^{+}$Corresponding author

e-mail: zhzhong@yic.ac.cn

Abbreviations: $\mathrm{Chl}$ - chlorophyll; $\mathrm{F}_{0}$ - minimal fluorescence yield of the dark-adapted state; $\mathrm{F}_{\mathrm{m}}$ - maximal fluorescence yield of the dark-adapted state; $F_{\mathrm{m}}{ }^{\prime}$ - maximal fluorescence yield of the light-adapted state; $F_{\mathrm{s}}$ - steady-state fluorescence yield; $F_{\mathrm{v}} / \mathrm{F}_{\mathrm{m}}-$ maximal quantum yield of PSII photochemistry; NPQ - nonphotochemical quenching; $\mathrm{q}_{\mathrm{E}}$ - energy-dependent quenching; RGR - relative growth rate; ROS - reactive oxygen species; $\Phi_{\mathrm{PSI}}$ - effective quantum yield of PSII photochemistry.

Acknowledgements: This work was supported by the National Key Research and Development Program of China (2016YFC1402106), the Technology Innovation Development Program of Yantai (2020MSGY058), the Key R \& D Projects in Shandong Province (International Scientific and Technical Cooperation) (2019GHZ026), the Shandong Provincial Natural Science Foundation, China (ZR201807120023), the Technology Innovation Development Program of Yantai (2020MSGY055), the Technology Innovation Development Program of Yantai (2020MSGY068), and 2020 Introduced Talent Project of Key Supported Area in Shandong Province, China.

Conflict of interest: The authors declare that they have no conflict of interest. 
an acid rain-affected region, in which Jinhua and Ningbo cities received large quantities of acid rain, and the $\mathrm{pH}$ was below 4.12 and 4.74, respectively (Zhang et al. 2007a, Ding et al. 2012). Additionally, acid rain was in the $\mathrm{pH}$ range of 3.24-6.56 in Wenzhou (Gao et al. 2016). In Shandong Province, Qingdao was a city with serious acid rain pollution, where the frequency of acid rain was high from 1993 to 2012, reaching 55\% (Xing et al. 2017). Particularly, in 2008, the average $\mathrm{pH}$ of precipitation in Qingdao was 4.4 (Xing et al. 2017). In China, the main causes of acid rain are the burning of a large amount of coal with high sulfur contents and vehicle emissions (Kita et al. 2004). Emissions from motor vehicles generated concentrated nitrogen oxides and $\mathrm{SO}_{2}$, which led to a gradual increase in acid rain (Singh and Agrawal 2008). Therefore, in the early $21^{\text {st }}$ century, the Chinese government adopted a series of measures for energy conservation and emission reduction. However, acid rain pollution remained severe in the southern and southwestern regions, which directly or indirectly affected the physiological and ecological processes in plants, and plants were facing more and more adverse stress (Liu et al. 2019).

In recent years, related studies have shown that acid rain could directly affect higher plants by destroying the leaf structure, reducing chlorophyll (Chl) fraction, and changing Chl fluorescence characteristics and enzyme activity (Singh and Agrawal 2008, Zhou et al. 2020, Hu et al. 2021). A study has found that acid rain could destroy the structure and integrity of chloroplasts and weaken photosynthesis in plants (Mubarakshina et al. 2006). This is because acid rain destroys the coupling between the thylakoid electron transport chain and photophosphorylation, which makes chloroplasts unable to properly complete the absorption, transfer, and conversion of light energy (Sun et al. 2011). Most studies on acid rain involved the causes, temporal and spatial distribution, control measures, mechanisms of the damage to crops and conifers, and impacts on water or land ecosystems (Debnath et al. 2018, Ju et al. 2020, Zhang et al. 2020). However, studies on the impacts of acid rain on macroalgae in the intertidal zone were scarce (Polishchuk et al. 2016).

Nearly 6,500 macroalgae species have been recorded in the world and macroalgae have a variety of ecological functions, including material absorption and release, food supply, and space shelter for aquatic organisms (Zhang et al. 2007b). Macroalgae mainly distribute in the subtidal zone and intertidal zone. Under the tidal action, they are periodically exposed to amphibious environments. As a result, they often experience diurnal and seasonal fluctuations in physical environmental factors, such as temperature, light, osmotic pressure, and drought (Levin et al.2015). During low tide, they are often exposed directly to acid rain that may last for several hours. Especially, at the lowest tide, acid rain falls to the intertidal zone, the algal ambient salinity may drop to $1 \%$ o (Xu et al. 2018), and the $\mathrm{pH}$ drops to a lower value, thus the growth and photosynthesis of intertidal macroalgae could be affected by acid rain. Li et al. (2017) found that after cultivating $U$. prolifera in simulated acid rain $(\mathrm{pH} 4.4)$ for $3 \mathrm{~d}$, the content of Chl $a$, the maximal quantum yield of PSII photochemistry $\left(\mathrm{F}_{\mathrm{v}} / \mathrm{F}_{\mathrm{m}}\right)$, and effective quantum yield of
PSII photochemistry $\left(\Phi_{\text {PSII }}\right)$ all declined, leading to a lower relative growth rate (RGR). Nonphotochemical quenching (NPQ) is one of the most important mechanisms of protection against rapid and high light, by which the excess light energy can be dissipated in heat by a light-harvesting complex (LHC), thus preventing the overexcitation of photochemical reactions (Baker 2008). Liu et al. (2020) exposed $U$. prolifera to acid $(\mathrm{pH} 4.0)$ and high light $\left[1,200 \mu \mathrm{mol}\left(\right.\right.$ photon) $\left.\mathrm{m}^{-2} \mathrm{~s}^{-1}\right]$ for 1 and $3 \mathrm{~h}$ and found NPQ values were higher than that of $U$. prolifera cultured under normal conditions. The result showed that acid treatment and the combined treatment of acid and high light could induce energy dissipation. In addition, a study showed that the macroalgae diversity in the intertidal zone along the coast of Wenzhou, Zhejiang, China, has been seriously damaged over the past few years due to acid rain (Zheng et al. 2011). Most macroalgae populations were reduced and even disappeared in the Nanji Islands, Wenzhou, while several other macroalgae reproduced quickly, including Corallina pilulifera, Lithophyllum okamurae, and Amphiroa anceps (Sun et al. 2010, Tang et al. 2014).

In addition to $\mathrm{pH}$, salinity could be dramatically reduced in the intertidal zone with the increase of precipitation in time and amount. Salinity affects the osmotic pressure, floatability, nutrient absorption, and photosynthetic oxygen evolution of algae cells to a certain point. Low salinity could inhibit the photosynthetic activity of Ulva pertusa and reduce the rate of oxygen evolution (Yamochi 2013). These results suggested the possibility of controlling a green tide of $U$. pertusa by a combination of exposure to air with low salinity. The impacts of low salinity on marine macroalgae vary from species to species, and the tolerance to low salinity depends mainly on their growth conditions and adaptive capacity (Karsten 2007). Low salinity affected the photosynthetic activity of macroalgae by altering osmotic pressure like in Ulva fasciata (Chen and Zou 2015) and Griffithsia monilis (Bisson and Kirst 1979). Allakhverdiev et al. (2002) found that salt stress inhibited the repair of photodamaged PSII in Synechocystis. However, few studies are available on the combined impacts of $\mathrm{pH}$ and salinity on the photosynthetic activity of macroalgae in the intertidal zone.

$U$. prolifera distributes in the intertidal zone and is known for its tolerance to a wide range of temperature and salinity (Gao et al. 2010). More importantly, it can trigger green tides, causing marine environmental pollution and economic losses (Yabe et al. 2009). Acid rain is one of the ten major environmental problems in the world (Larssen et al.2006) and it is fundamentally unknown how acid rain mediates the impact of salinity changes on $U$. prolifera. Therefore, the combined impacts of $\mathrm{pH}$ and salinity on the $\mathrm{F}_{\mathrm{v}} / \mathrm{F}_{\mathrm{m}}$ and $\Phi_{\mathrm{PSII}}$ of $U$. prolifera in different durations were studied; 27 gradients of $\mathrm{pH}$, salinity, and treatment duration were set up and NPQ values were measured to understand the ability of $U$. prolifera in self-regulation under acid rain.

\section{Materials and methods}

Sample collection and culture conditions: Samples of $U$. prolifera were collected from the intertidal zone at The 
First Bathing Beach $\left(36.06^{\circ} \mathrm{N}, 120.35^{\circ} \mathrm{E}\right)$, Qingdao, China on 20 July 2020 (Fig. 1), and the thalli were carried to laboratory in an icebox within $24 \mathrm{~h}$. In the laboratory, the thalli were rinsed gently in filtered nature seawater at least three times to remove epiphytes, sediments, grazers, and other attached materials, and then cultured with filtered $(0.22 \mu \mathrm{m})$ and autoclaved natural seawater (salinity of $30 \%$ ), in which $\mathrm{NaNO}_{3}\left(100 \mu \mathrm{mol} \mathrm{L}^{-1}\right)$ and $\mathrm{KH}_{2} \mathrm{PO}_{4} \cdot 12 \mathrm{H}_{2} \mathrm{O}$ $\left(10 \mu \mathrm{mol} \mathrm{L} \mathrm{L}^{-1}\right)$ were added. The thalli were cultured in an illuminated incubator ( $G X Z-380 C$, Ningbo, China) at $20 \pm 1^{\circ} \mathrm{C}$ under irradiance of $100 \mu \mathrm{mol}\left(\right.$ photon) $\mathrm{m}^{-2} \mathrm{~s}^{-1}$ $(12 / 12 \mathrm{~h} \mathrm{light} /$ dark period) with ambient airing. After $2 \mathrm{~d}$, tender and healthy thalli ( $3 \mathrm{~cm}$ in length) were chosen for experiments.

Experimental design: Well-grown U. prolifera $(\mathrm{CK})$ was cultured in natural seawater $(\mathrm{pH} 8.2$, salinity of $30 \% \mathrm{o})$. The $\mathrm{pH}$ and salinity were measured with a $P 611$ portable pH-meter (YOKE, Shanghai, China) and a portable salinometer (DAIKELI, Anhui, China). Salinities were set at $1 \%$ and $10 \%$ by diluting filterable natural seawater with distilled water, and $\mathrm{pH}$ of different salinity $(1,10$, and $30 \%$ ) of seawater was set at 3.0, 3.5, and 4.5, using a mixed solution of $\mathrm{H}_{2} \mathrm{SO}_{4}\left(\mathrm{~mol} \mathrm{~L}^{-1}\right): \mathrm{HNO}_{3}\left(1 \mathrm{~mol} \mathrm{~L}^{-1}\right)=2: 1$ (Li et al. 2017). Nine different conditions were simulated.

\begin{tabular}{|c|c|c|c|}
\hline Treatments & $\mathrm{pH} 3.0$ & $\mathrm{pH} 3.5$ & $\mathrm{pH} 4.5$ \\
\hline $\begin{array}{l}\text { Salinity 1\%o } \\
\text { (S 1) }\end{array}$ & $\mathrm{S} 1-\mathrm{pH} 3.0$ & $\mathrm{~S} 1-\mathrm{pH} 3.5$ & $\mathrm{~S} 1-\mathrm{pH} 4.5$ \\
\hline $\begin{array}{l}\text { Salinity 10\%o } \\
\text { (S 10) }\end{array}$ & $\mathrm{S} 10-\mathrm{pH} 3.0$ & $\mathrm{~S} 10-\mathrm{pH} 3.5$ & $\mathrm{~S} 10-\mathrm{pH} 4.5$ \\
\hline $\begin{array}{l}\text { Salinity 30\%o } \\
\text { (S 30) }\end{array}$ & $\mathrm{S} 30-\mathrm{pH} 3.0$ & $\mathrm{~S} 30-\mathrm{pH} 3.5$ & $\mathrm{~S} 30-\mathrm{pH} 4.5$ \\
\hline
\end{tabular}

The healthy thalli were submersed into these nine different conditions for $0.5,1$, and $2 \mathrm{~h}$ before Chl fluorescence determination. Each treatment was performed in triplicates $(n=3)$. Chl fluorescence was determined again after thalli were taken back into normal natural conditions for $24 \mathrm{~h}$, and the culture conditions were consistent with those mentioned above.

Chl fluorescence parameters: The photosynthetic parameters were measured at room temperature $(20 \pm$ $1{ }^{\circ} \mathrm{C}$ ) using a Closed FluorCam FC 800-C (PSI, Czech Republic). The thalli were kept in darkness for $15 \mathrm{~min}$ and then the minimal fluorescence yield of the dark-adapted state $\left(\mathrm{F}_{0}\right)$ was measured. The intensity of measuring flashes is $0.02 \mu \mathrm{mol}$ (photon) $\mathrm{m}^{-2} \mathrm{~s}^{-1}$ in $10-\mu \mathrm{s}$ pulse to remain nonactinic. The maximal fluorescence yield of the darkadapted state $\left(\mathrm{F}_{\mathrm{m}}\right)$ was measured when a saturation pulse was applied. Saturation pulse was cold white light, and its irradiance and pulse length were 3,370 $\mu$ mol(photon) $\mathrm{m}^{-2} \mathrm{~s}^{-1}$ and $800 \mathrm{~ms}$, respectively. The actinic light treatment was applied for $60 \mathrm{~s}$. Five saturation pulses were given during actinic light and the intervals were 10,10,20, and $20 \mathrm{~s}$. The $\mathrm{F}_{\mathrm{v}} / \mathrm{F}_{\mathrm{m}}$ was calculated as $\mathrm{F}_{\mathrm{v}} / \mathrm{F}_{\mathrm{m}}=\left(\mathrm{F}_{\mathrm{m}}-\mathrm{F}_{0}\right) / \mathrm{F}_{\mathrm{m}}$ and the $\Phi_{\text {PSII }}$ was calculated as $\Phi_{\text {PSII }}=\left(F_{m}{ }^{\prime}-F_{s}\right) / F_{m}{ }^{\prime}$, where $F_{m}{ }^{\prime}$ is the maximal fluorescence level from algae induced by

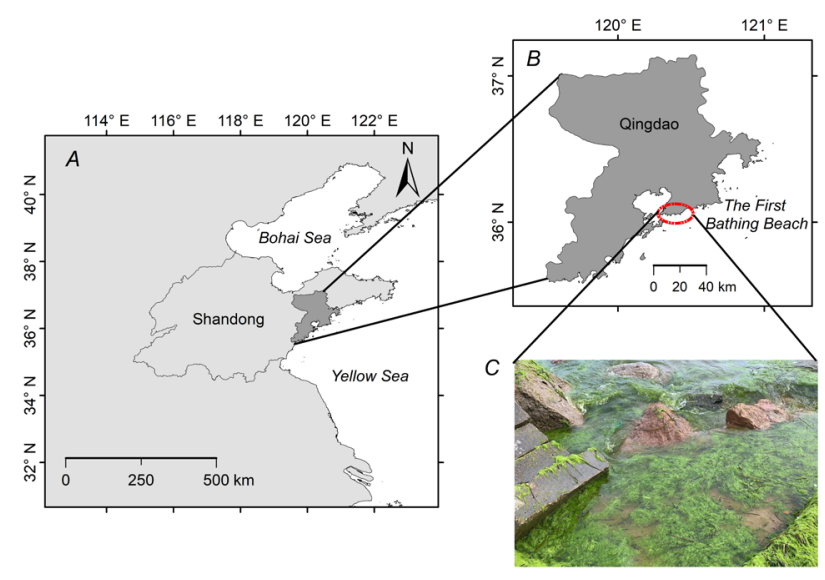

Fig. 1. The sampling place for Ulva prolifera in The First Bathing Beach, Qingdao, Shangdong, China. $(A, B)$ The geographical position; $(C)$ the sampling scene of the intertidal zone in the place.

a saturation pulse under active light of $104 \mu \mathrm{mol}$ (photon) $\mathrm{m}^{-2} \mathrm{~s}^{-1}$ (close to the cultured irradiance) and $F_{\mathrm{s}}$ is steadystate fluorescence yield. NPQ reflects the downregulation of PSII as a protective mechanism against excess light intensity, which was calculated as NPQ $=\left(F_{m}-F_{m}{ }^{\prime}\right) / F_{m}{ }^{\prime}$.

Statistical analysis: All data were analyzed using Origin 8.5 (OriginLab, USA) and SPSS 25.0 (IBM, Chicago, USA). A map was made by ArcGIS 10.2 (ESRI, USA). Statistical differences under the different treatment conditions were analyzed with the repeated-measures analyses of variance (RM-ANOVA), followed by Tukey's honestly significant difference posthoc test. Before all statistical analyses, the homogeneity of variances was verified by Levene's test. Partial eta squared $\left(\eta^{2}\right)$ was used to measure the effect size. $P<0.05$ was considered significant and a confidence interval of $95 \%$ was set for all tests. All data were expressed as mean \pm standard deviation $(\mathrm{SD}, n=3)$.

\section{Results}

Impacts of $\mathrm{pH}$ and treatment duration on $\mathrm{F}_{\mathrm{v}} / \mathrm{F}_{\mathrm{m}}$ and $\boldsymbol{\Phi}_{\text {PSII }}$ : The impacts of $\mathrm{pH}$ and treatment duration on the $\mathrm{F}_{\mathrm{v}} / \mathrm{F}_{\mathrm{m}}$ and $\Phi_{\text {PSII }}$ of $U$. prolifera are shown in Fig. 2 . The $\mathrm{F}_{\mathrm{v}} / \mathrm{F}_{\mathrm{m}}$ and $\Phi_{\mathrm{PSII}}$ declined significantly with the decrease of $\mathrm{pH}$ (Fig. 2). At pH 3 after $0.5 \mathrm{~h}$, the $\mathrm{F}_{\mathrm{v}} / \mathrm{F}_{\mathrm{m}}$ and $\Phi_{\text {PSII }}$ declined significantly and only 70.8 and $64.1 \%$ of the CK could be recovered, respectively (Fig. 2). The $\mathrm{F}_{\mathrm{v}} / \mathrm{F}_{\mathrm{m}}$ and $\Phi_{\text {PSII }}$ were severely lowered and could not recover with the treatment duration increase. The $\mathrm{F}_{\mathrm{v}} / \mathrm{F}_{\mathrm{m}}$ and $\Phi_{\text {PSII }}$ of $1-\mathrm{h}$ treatment were only 22.9 and $21.4 \%$ of those in 0.5 -h treatment, respectively, and those in $2-\mathrm{h}$ treatment declined to 0 . The $\mathrm{F}_{\mathrm{v}} / \mathrm{F}_{\mathrm{m}}$ and $\Phi_{\text {PSII }}$ could recover and approach the CK level when $U$. prolifera was under $\mathrm{pH} 3.5$ for 0.5 h-duration treatment. However, with treatment duration increase, the $\mathrm{F}_{\mathrm{v}} / \mathrm{F}_{\mathrm{m}}$ and $\Phi_{\mathrm{PSII}}$ could recover partially only $(1 \mathrm{~h})$ or failed to recover $(2 \mathrm{~h})$.

$R M-A N O V A$ analysis showed that $\mathrm{pH}$ and treatment duration had an interactive effect on the $\mathrm{F}_{\mathrm{v}} / \mathrm{F}_{\mathrm{m}}$ and $\Phi_{\mathrm{PSII}}$ 
of $U$. prolifera (Table 1S, supplement). Moreover, $\mathrm{pH}$ was demonstrated as the most important contributor to the $\mathrm{F}_{\mathrm{v}} / \mathrm{F}_{\mathrm{m}}$ and $\Phi_{\text {PSII }}$ change as the magnitude of $\eta^{2}$ indicated $\left(\mathrm{F}_{\mathrm{v}} / \mathrm{F}_{\mathrm{m}}: 1.622>0.237\right.$; $\left.\Phi_{\text {PSII }}: 1.426>0.094\right)$.

$\mathbf{F}_{\mathrm{v}} / \mathbf{F}_{\mathbf{m}}$ and $\boldsymbol{\Phi}_{\text {PSII }}$ under low $\mathbf{p H}$ conditions: We studied how salinity affected photosynthetic activity under low $\mathrm{pH}$ (3.5) conditions (Fig. 3). The $\mathrm{F}_{\mathrm{v}} / \mathrm{F}_{\mathrm{m}}$ remained at a normal level after treatment for $0.5 \mathrm{~h}$ (Fig. $3 A$ ). But under longtime treatment (1 and $2 \mathrm{~h}$ ), high salinity (S 30) was more conducive to maintain the $\mathrm{F}_{\mathrm{v}} / \mathrm{F}_{\mathrm{m}}$ and $\Phi_{\mathrm{PSII}}$ than low salinity (S 1 and S 10) (Fig. 3) did. The $\mathrm{F}_{\mathrm{v}} / \mathrm{F}_{\mathrm{m}}$ and $\Phi_{\mathrm{PSII}}$ treated in salinity of $30 \%$ for $1 \mathrm{~h}$ were 87.3 and $81.5 \%$ of $\mathrm{CK}$, while those treated in salinity of $10 \%$ could only reach 29.2 and $23.7 \%$ of $\mathrm{CK}$, respectively.

In addition, $R M-A N O V A$ analysis showed that salinity and treatment duration had an interactive effect on the

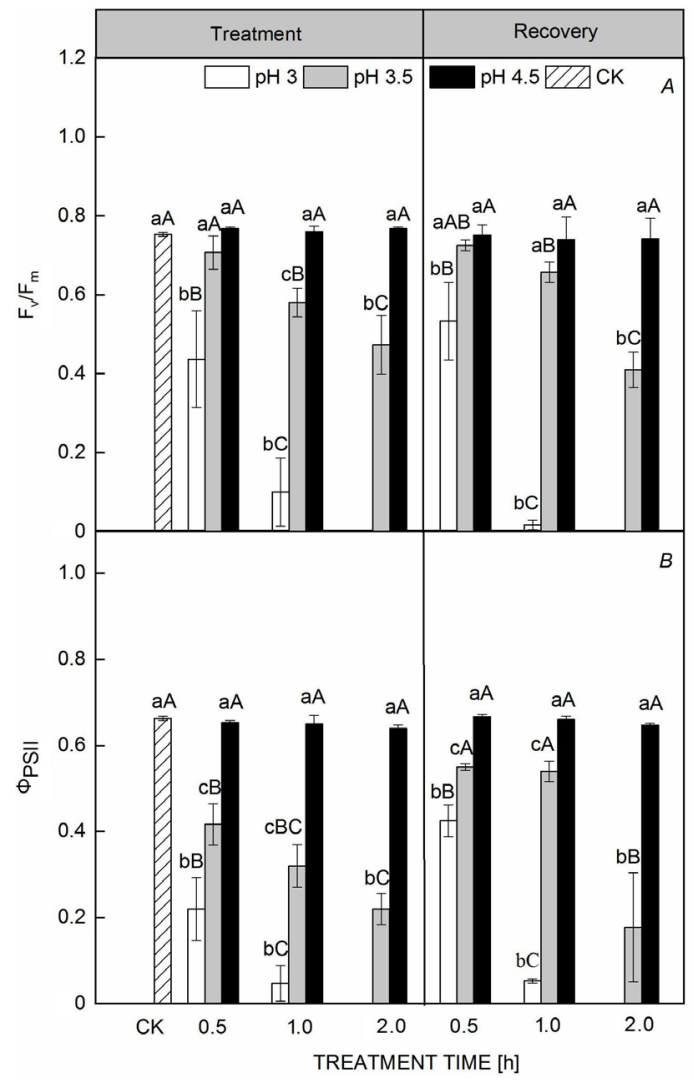

Fig. 2. The maximal quantum yield of PSII photochemistry $\left(\mathrm{F}_{\mathrm{v}} / \mathrm{F}_{\mathrm{m}}\right)(A)$ and effective quantum yield of PSII photochemistry $\left(\Phi_{\mathrm{PSII}}\right)(B)$ of Ulva prolifera after treatment in a different $\mathrm{pH}$ at salinity $30 \%$ for a different duration $(0.5,1$, and $2 \mathrm{~h})$, and those after recovery under natural growth condition for $24 \mathrm{~h}$. CK is the well-grown $U$. prolifera under normal growth conditions. The different lowercase letters over the bars indicate significant differences (compared to $\mathrm{CK}$ ) between $\mathrm{pH}$ treatments at the same treatment duration or recovery duration, while the different uppercase letters over the bars indicate significant differences (compared to $\mathrm{CK}$ ) between treatment duration or recovery duration at the same $\mathrm{pH}$. Data are represented as means $\pm \mathrm{SD}$ and the values are the means of three replications. $P<0.05$ was considered significant.
$\mathrm{F}_{\mathrm{v}} / \mathrm{F}_{\mathrm{m}}$ and $\Phi_{\mathrm{PSII}}$ of $U$. prolifera under low $\mathrm{pH}$ (3.5) conditions (Table 2S, supplement). The order of contribution to the variability of $\mathrm{F}_{\mathrm{v}} / \mathrm{F}_{\mathrm{m}}$ and $\Phi_{\text {PSII }}$ as shown in $\eta^{2}$ was salinity $<$ treatment duration $\left(\mathrm{F}_{\mathrm{v}} / \mathrm{F}_{\mathrm{m}}: 0.577<1.379 ; \Phi_{\mathrm{PSII}}\right.$ : $0.119<0.775)$.

NPQ variations: The impacts of $\mathrm{pH}$ and treatment duration on the NPQ of $U$. prolifera are described in Fig. $4 A$. The NPQ of CK was $0.1 \pm 0.005$, but that of the three $\mathrm{pH}(3,3.5,4.5)$ treatments increased to $0.21 \pm 0.11$, $0.58 \pm 0.08$, and $0.25 \pm 0.03$ in $0.5 \mathrm{~h}$, respectively. In addition, we studied how salinity affected NPQ under low $\mathrm{pH}$ (3.5) conditions (Fig. 4B). The results showed NPQ under salinity of $30 \%$ was much higher than that under salinity of $1 \%$ and $10 \%$ o (Figs. $4 B, 5$ ). After treatment for $1 \mathrm{~h}$, NPQ under salinity of $30 \%$ was 2.68 times and 3.26 times that under salinity of $1 \%$ and $10 \%$, respectively;

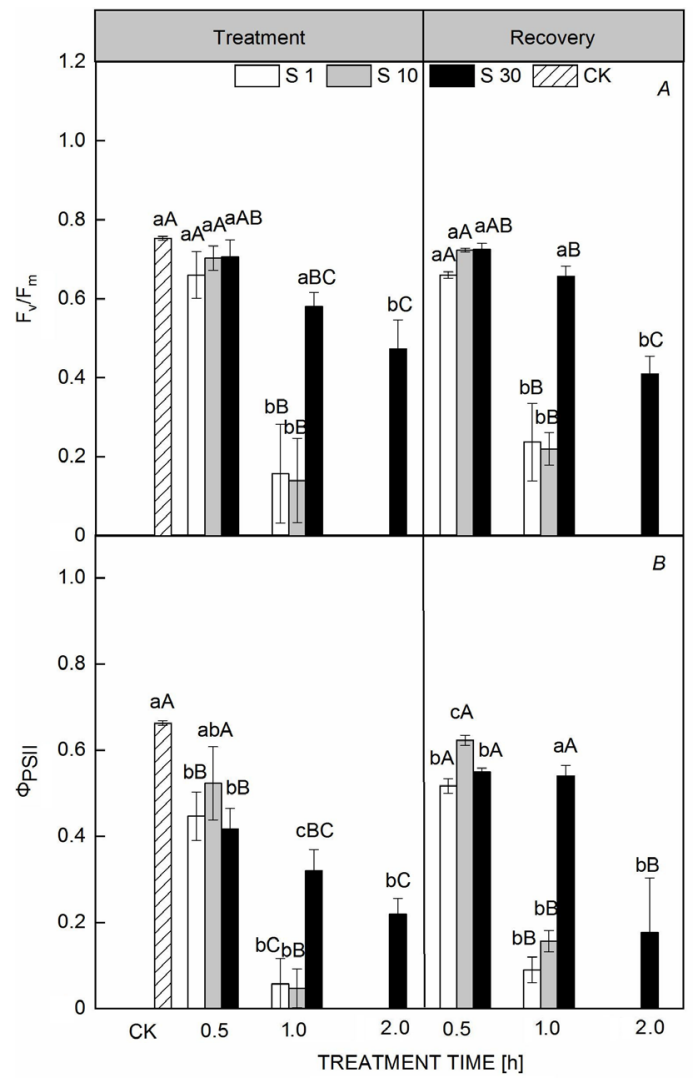

Fig. 3. The maximal quantum yield of PSII photochemistry $\left(\mathrm{F}_{\mathrm{v}} / \mathrm{F}_{\mathrm{m}}\right)(A)$ and effective quantum yield of PSII photochemistry $\left(\Phi_{\mathrm{PSII}}\right)(B)$ of Ulva prolifera after treatment in a different salinity at $\mathrm{pH} 3.5$ for a different duration $(0.5,1$, and $2 \mathrm{~h})$, and those after recovery under natural growth conditions for $24 \mathrm{~h}$. CK is the well-grown $U$. prolifera under normal growth conditions. The different lowercase letters over the bars indicate significant differences (compared to CK) between salinity treatments at the same treatment duration or recovery duration, while the different uppercase letters over the bars indicate significant differences (compared to $\mathrm{CK}$ ) between treatment duration or recovery duration at the same salinity. Data are represented as means \pm SD and the values are the means of three replications. $P<0.05$ was considered significant. 


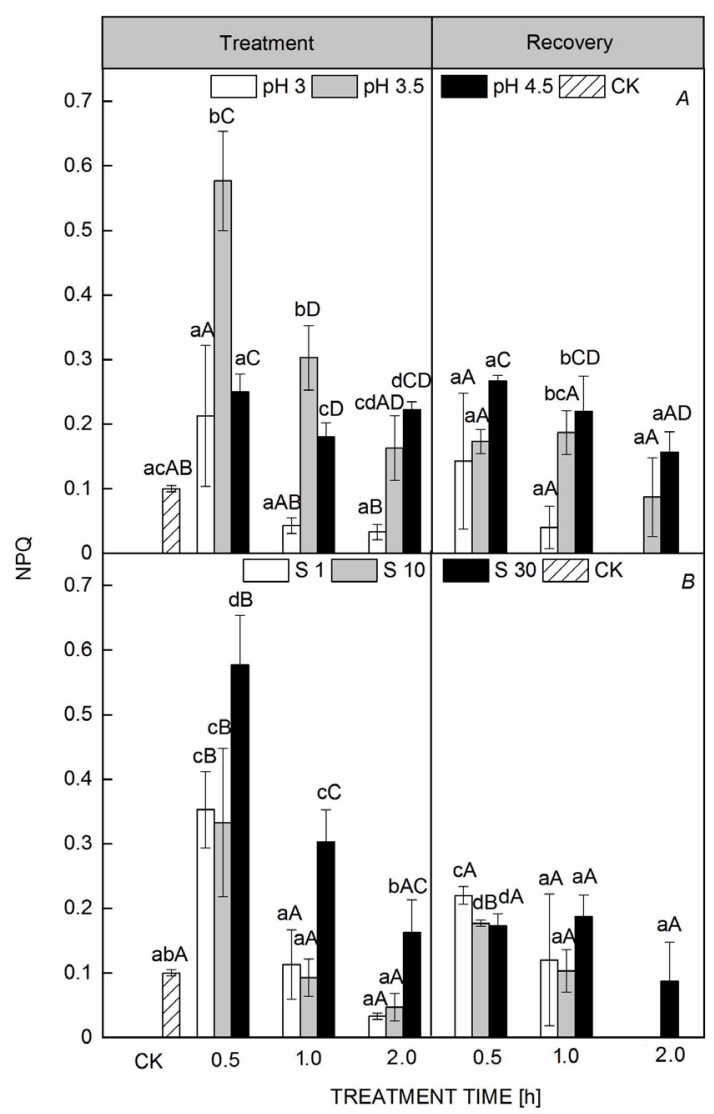

Fig. 4. (A) The nonphotochemical quenching (NPQ) of Ulva prolifera after treatment in a different $\mathrm{pH}$ at salinity $30 \%$ for a different duration $(0.5,1$, and $2 \mathrm{~h}$ ), and those after recovery under natural growth conditions for $24 \mathrm{~h}$. The different lowercase letters over the bars indicate significant differences (compared to $\mathrm{CK}$ ) between $\mathrm{pH}$ treatments at the same treatment duration or recovery duration, while the different uppercase letters over the bars indicate significant differences (compared to CK) between treatment duration or recovery duration at the same $\mathrm{pH}$. $(B)$ The NPQ of $U$. prolifera after treatment in a different salinity at $\mathrm{pH} 3.5$ for a different duration, and those after recovery under natural growth conditions for $24 \mathrm{~h}$. The different lowercase letters over the bars indicate significant differences (compared to CK) between salinity treatments at the same treatment duration or recovery duration, while the different uppercase letters over the bars indicate significant differences (compared to CK) between treatment duration or recovery duration at the same salinity. CK is the well-grown $U$. prolifera under normal growth conditions. Data are represented as means $\pm \mathrm{SD}$ and the values are the means of three replications. $P<0.05$ was considered significant.

and for $2 \mathrm{~h}$-duration treatment, NPQ under salinity of $30 \%$ was 4.94 times and 3.47 times that under salinity of $1 \%$ and $10 \%$, respectively.

Impacts of $\mathrm{pH}$, salinity, and treatment duration on $\mathbf{F}_{\mathrm{v}} / \mathbf{F}_{\mathrm{m}}$ and $\boldsymbol{\Phi}_{\text {PsII }}$ : An acid rain often lasts for several hours, resulting in low $\mathrm{pH}$ and salinity. Therefore, we selected $0.5,1$, and $2 \mathrm{~h}$ to evaluate the impacts of $\mathrm{pH}$ and salinity on the $\mathrm{F}_{\mathrm{v}} / \mathrm{F}_{\mathrm{m}}$ and $\Phi_{\mathrm{PSII}}$ of $U$. prolifera (Fig. 6). When salinity and treatment duration did not change, the decrease of $\mathrm{pH}$

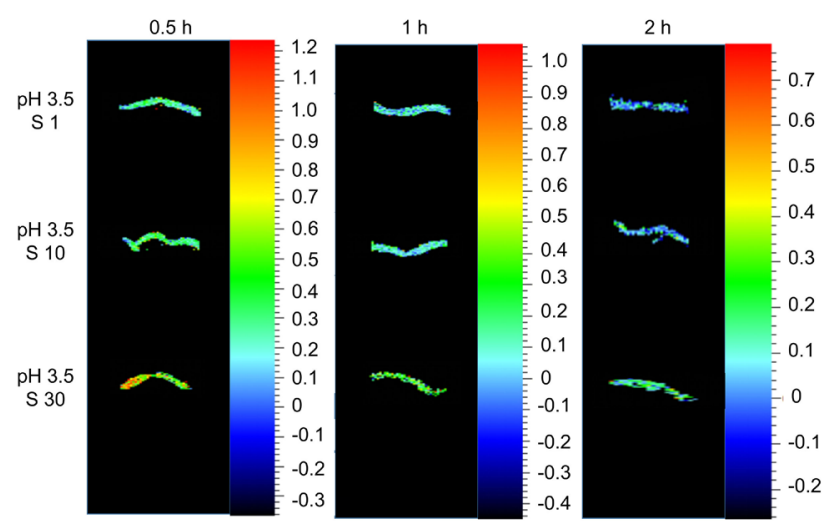

Fig. 5. Fluorescence imaging of nonphotochemical quenching (NPQ) after treatment in a different salinity at $\mathrm{pH} 3.5$ for a different duration $(0.5,1$, and $2 \mathrm{~h})$. The different colors represent different NPQ values. S 1, S 10 , and S 30 represent salinity of $1 \%$, $10 \%$, and $30 \%$, respectively.

inhibited the $\mathrm{F}_{\mathrm{v}} / \mathrm{F}_{\mathrm{m}}$ and $\Phi_{\mathrm{PSII}}$ of $U$.prolifera (Figs. 6, 7). Low salinity (S 1 and $S 10$ ) inhibited the $F_{v} / F_{m}$ and $\Phi_{\text {PSII }}$ of $U$. prolifera under low $\mathrm{pH}(3,3.5)$ conditions (Figs. 6, 7). Importantly, the $F_{\mathrm{v}} / \mathrm{F}_{\mathrm{m}}$ and $\Phi_{\text {PSII }}$ were not significantly affected at $\mathrm{pH} 4.5$ (Figs. 6, 7). Under $\mathrm{pH} 3.5$ and salinity of $30 \%$, the $\mathrm{F}_{\mathrm{v}} / \mathrm{F}_{\mathrm{m}}$ and $\Phi_{\mathrm{PSII}}$ of $U$. prolifera treated for $0.5 \mathrm{~h}$ could restore to 96.3 and $83.0 \%$ of $\mathrm{CK}$ level after $24-\mathrm{h}$ recovering. However, the $\mathrm{F}_{\mathrm{v}} / \mathrm{F}_{\mathrm{m}}$ and $\Phi_{\mathrm{PSII}}$ continued declining and could not recover with treatment duration increased and salinity decreased. When $\mathrm{pH}$ dropped to 3 , the $\mathrm{F}_{\mathrm{v}} / \mathrm{F}_{\mathrm{m}}$ and $\Phi_{\text {PSII }}$ declined significantly and could not recover (Fig. 6).

Results of RM-ANOVA showed that $\mathrm{pH}$, salinity, and treatment duration had an interactive effect on the $\mathrm{F}_{\mathrm{v}} / \mathrm{F}_{\mathrm{m}}$ and $\Phi_{\text {PSII }}$ of $U$. prolifera (Table 1). The effects that contributed to the variability of $\mathrm{F}_{\mathrm{v}} / \mathrm{F}_{\mathrm{m}}$ and $\Phi_{\text {PSII }}$ in the order of $\eta^{2}$ were $\mathrm{pH}>$ salinity $>\mathrm{pH} \times$ salinity $\left(\mathrm{F}_{\mathrm{v}} / \mathrm{F}_{\mathrm{m}}: 6.545>\right.$ $0.506>0.264$; $\left.\Phi_{\mathrm{PSII}}: 5.257>0.116>0.052\right)$.

\section{Discussion}

The low $\mathrm{pH}$ induced by acid rain can alter community structure and species richness (Raut et al. 2012, Gao et al. 2016) via damaging their cell membrane, destroying photosystem, or disordering signal transduction (Liu et al. 2014). In this study, we found that $F_{v} / F_{m}$ and $\Phi_{\text {PSII }}$ of U. prolifera kept normal levels under $\mathrm{pH}$ 4.5. Li et al. (2017) also found similar results and no significant differences in RGR of $U$. prolifera were observed between normal seawater ( $\mathrm{pH} 8.2)$ and $\mathrm{pH} 4.4$ treatment. Differently, when $U$. prolifera was under $\mathrm{pH} 3.5$ for $0.5 \mathrm{~h}, \mathrm{~F}_{\mathrm{v}} / \mathrm{F}_{\mathrm{m}}$ and $\Phi_{\mathrm{PSII}}$ declined sharply but could recover to CK level after 24-h recovering, while the $\mathrm{F}_{\mathrm{v}} / \mathrm{F}_{\mathrm{m}}$ and $\Phi_{\mathrm{PSII}}$ could not recover after longer treatments ( 1 and $2 \mathrm{~h})$. On the other hand, when the $\mathrm{pH}$ dropped to $3, \mathrm{~F}_{\mathrm{v}} / \mathrm{F}_{\mathrm{m}}$ and $\Phi_{\text {PSII }}$ could not recover at all treatment durations. The possible reason is that $U$.prolifera is composed of monolayer cells, which is favorable for the entry of $\mathrm{H}^{+}$(Liu et al. 2020). Gómez et al. (2004) found that $\mathrm{H}^{+}$could cause photoinhibition and further affect the 


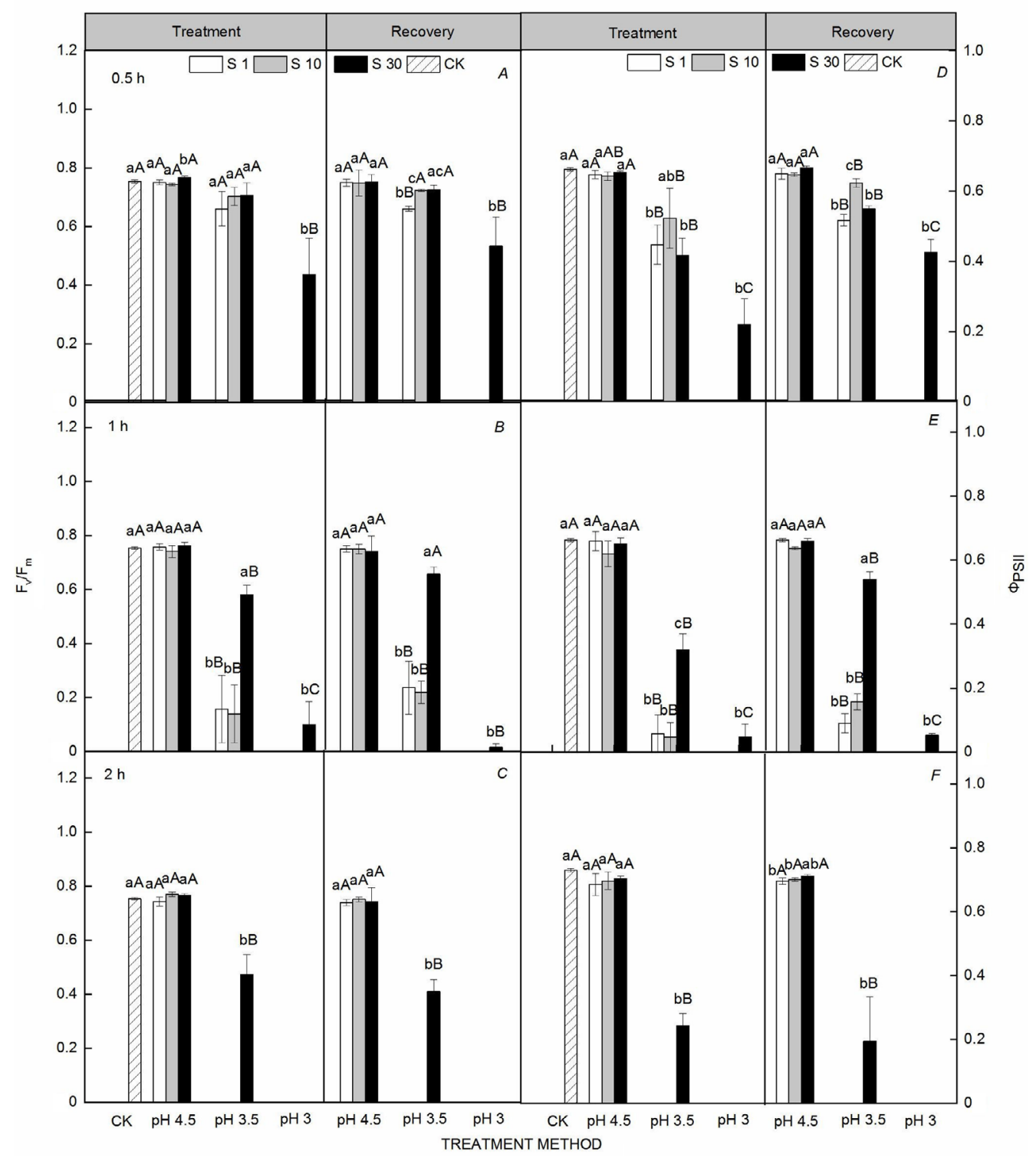

Fig. 6. The maximal quantum yield of PSII photochemistry $\left(\mathrm{F}_{\mathrm{v}} / \mathrm{F}_{\mathrm{m}}\right)(A-C)$ and effective quantum yield of PSII photochemistry $\left(\Phi_{\mathrm{PSII}}\right)$ $(D-F)$ of Ulva prolifera after treatment under different $\mathrm{pH}$ and salinity values for a different duration $(0.5,1$, and $2 \mathrm{~h})$, and those after recovery under natural growth conditions for $24 \mathrm{~h}$. CK is the well-grown $U$. prolifera under normal growth conditions. The different lowercase letters over the bars indicate significant differences (compared to CK) between salinity treatments at the same treatment duration or recovery duration and the same $\mathrm{pH}$, while the different uppercase letters over the bars indicate significant differences (compared to $\mathrm{CK}$ ) between $\mathrm{pH}$ at the same salinity and treatment duration or recovery duration. Data are represented as means $\pm \mathrm{SD}$ and the values are the means of three replications. $P<0.05$ was considered significant.

protein synthesis and degradation in PSII. Ma et al. (2020) found that $\mathrm{H}^{+}$led to the degradation of PSII reaction center proteins D1, and reduced the ability to utilize light energy in red alga Pyropia yezoensis. In addition, some studies found that $\mathrm{H}^{+}$could destroy Rieske FeS protein and cytochrome (Cyt) $f$ protein in Cyt $b_{6} f$ complex, further damage PSI, and reduce the photosynthetic activity of U. prolifera (Yamori et al. 2011, Liu et al. 2020). In severe cases, $\mathrm{H}^{+}$could cause DNA damage and irreversibly destroy the photosynthetic system (Gómez et al. 2004, Milligan et al. 2009). As shown in Table 1S, the impact of
$\mathrm{pH}$ on the $\mathrm{F}_{\mathrm{v}} / \mathrm{F}_{\mathrm{m}}$ and $\Phi_{\mathrm{PSII}}$ of $U$. prolifera was dominant in the order of $\eta^{2}$. Therefore, we thought that severe acid rain pollution (low $\mathrm{pH}$ or longer duration) would destroy the photosynthetic activity of $U$. prolifera.

Similarly, Gao et al. (2016) reported that the photosynthetic properties of Ulva conglobata decreased irreversibly under a low $\mathrm{pH}$ of 3 , indicating that it could not survive after encountering low $\mathrm{pH}$ induced by acid rain. Conversely, the photosynthetic performance of Corallina sp. could recover quickly in normal seawater after low $\mathrm{pH}$ treatment; the reason was that they could 

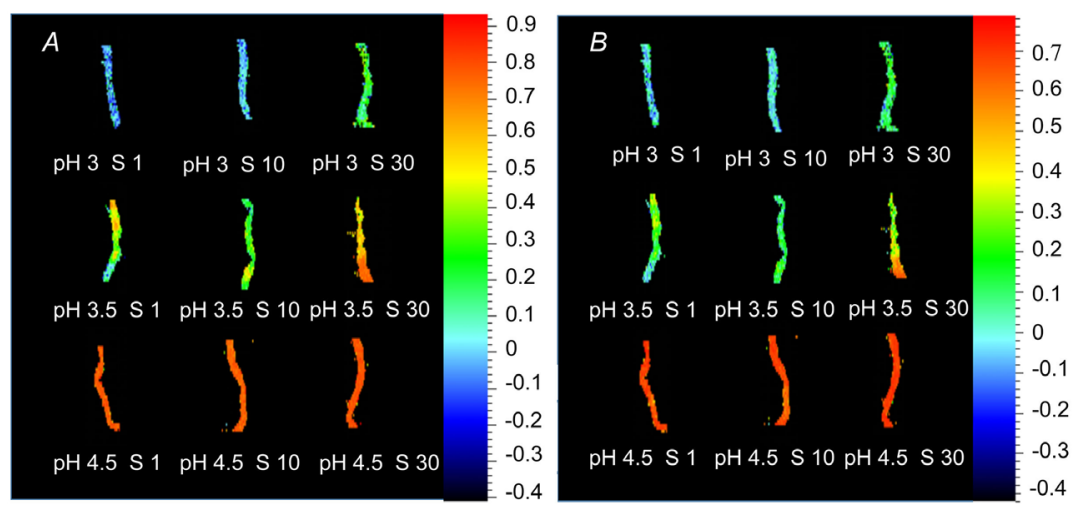

Fig. 7. Fluorescence imaging of maximal quantum yield of PSII photochemistry $\left(\mathrm{F}_{\mathrm{v}} / \mathrm{F}_{\mathrm{m}}\right)(A)$ and effective quantum yield of PSII photochemistry $\left(\Phi_{\mathrm{PSII}}\right)(B)$ after treatment under different $\mathrm{pH}$ and salinity values for 1-h duration. The different colors represent different $\mathrm{F}_{\mathrm{v}} / \mathrm{F}_{\mathrm{m}}(A)$ and $\Phi_{\mathrm{PSII}}(B)$ values. S $1, \mathrm{~S} 10$, and $\mathrm{S} 30$ represent salinity of 1,10 , and $30 \%$, respectively.

Table 1. Repeated-measure ANOVA (RM-ANOVA) statistics for impacts of salinity, $\mathrm{pH}$, and treatment duration on the maximal quantum yield of PSII photochemistry $\left(\mathrm{F}_{\mathrm{v}} / \mathrm{F}_{\mathrm{m}}\right)$ and effective quantum yield of PSII photochemistry $\left(\Phi_{\mathrm{PSII}}\right)$ of Ulva prolifera. $\eta^{2}-$ Partial eta squared; df - degree of freedom; $F-$ value of $F$ statistic; $P-P$ value.

\begin{tabular}{|c|c|c|c|c|c|c|c|c|c|c|}
\hline Variable & $\eta^{2}$ & $\mathrm{df}$ & Mean square & $F$ & $P$ & $\eta^{2}$ & df & Mean square & $F$ & $P$ \\
\hline & \multicolumn{5}{|c|}{$\mathrm{F}_{\mathrm{v}} / \mathrm{F}_{\mathrm{m}}$ in treatment stage } & \multicolumn{5}{|c|}{$F_{v} / F_{m}$ in recovery stage } \\
\hline & \multicolumn{10}{|c|}{ Within-subjects } \\
\hline Time $(\mathrm{T})$ & 0.737 & 2 & 0.369 & 88.849 & $<0.01$ & 0.893 & 2 & 0.447 & 240.593 & $<0.01$ \\
\hline $\mathrm{T} \times \mathrm{S}$ & 0.003 & 4 & 0.001 & 0.186 & $>0.05$ & 0.012 & 4 & 0.003 & 1.563 & $>0.05$ \\
\hline $\mathrm{T} \times \mathrm{pH}$ & 0.746 & 4 & 0.187 & 44.981 & $<0.01$ & 0.748 & 4 & 0.187 & 100.802 & $<0.01$ \\
\hline $\mathrm{T} \times \mathrm{S} \times \mathrm{pH}$ & 0.456 & 8 & 0.057 & 13.746 & $<0.01$ & 0.563 & 8 & 0.070 & 37.885 & $<0.01$ \\
\hline \multirow[t]{2}{*}{ Error in $\mathrm{T}$} & 0.149 & 36 & 0.004 & & & 0.067 & 36 & 0.002 & & \\
\hline & \multicolumn{10}{|c|}{ Between-subjects } \\
\hline Salinity (S) & 0.506 & 2 & 0.253 & 109.119 & $<0.01$ & 0.409 & 2 & 0.205 & 107.377 & $<0.01$ \\
\hline $\mathrm{pH}$ & 6.545 & 2 & 3.272 & $1,412.168$ & $<0.01$ & 5.262 & 2 & 2.631 & $1,381.018$ & $<0.01$ \\
\hline $\mathrm{S} \times \mathrm{pH}$ & 0.264 & 4 & 0.066 & 28.525 & $<0.01$ & 0.303 & 4 & 0.076 & 39.770 & $<0.01$ \\
\hline \multirow[t]{3}{*}{ Error in $\mathrm{S}$} & 0.042 & 18 & 0.002 & & & 0.034 & 18 & 0.002 & & \\
\hline & \multicolumn{5}{|c|}{$\Phi_{\text {PSII }}$ in treatment stage } & \multirow{2}{*}{\multicolumn{5}{|c|}{$\Phi_{\text {PSII }}$ in recovery stage }} \\
\hline & \multicolumn{5}{|c|}{ Within-subjects } & & & & & \\
\hline $\mathrm{T}$ & 0.384 & 2 & 0.192 & 89.334 & $<0.01$ & 0.675 & 2 & 0.337 & 184.924 & $<0.01$ \\
\hline $\mathrm{T} \times \mathrm{S}$ & 0.014 & 4 & 0.003 & 1.596 & $>0.05$ & 0.034 & 4 & 0.009 & 4.720 & $<0.01$ \\
\hline $\mathrm{T} \times \mathrm{pH}$ & 0.419 & 4 & 0.105 & 48.721 & $<0.01$ & 0.593 & 4 & 0.148 & 81.264 & $<0.01$ \\
\hline $\mathrm{T} \times \mathrm{S} \times \mathrm{pH}$ & 0.181 & 8 & 0.023 & 10.516 & $<0.01$ & 0.381 & 8 & 0.048 & 26.086 & $<0.01$ \\
\hline \multirow[t]{2}{*}{ Error in $\mathrm{T}$} & 0.077 & 36 & 0.002 & & & 0.066 & 36 & 0.002 & & \\
\hline & \multicolumn{10}{|c|}{ Between-subjects } \\
\hline S & 0.116 & 2 & 0.058 & 40.320 & $<0.01$ & 0.268 & 2 & 0.134 & 87.650 & $<0.01$ \\
\hline $\mathrm{pH}$ & 5.257 & 2 & 2.628 & $1,828.952$ & $<0.01$ & 4.848 & 2 & 2.424 & $1,583.134$ & $<0.01$ \\
\hline $\mathrm{S} \times \mathrm{pH}$ & 0.052 & 4 & 0.013 & 8.985 & $<0.01$ & 0.120 & 4 & 0.030 & 19.545 & $<0.01$ \\
\hline Error in $\mathrm{S}$ & 0.026 & 18 & 0.001 & & & 0.028 & 18 & 0.002 & & \\
\hline
\end{tabular}

regulate the $\mathrm{pH}$ of ambient seawater through dissolving their $\mathrm{CaCO}_{3}$. In addition, Sargassum vulgare could adapt to a low $\mathrm{pH}$ by upregulating the activities of oxidative metabolic enzymes (Kumar et al. 2017). The different responses to low $\mathrm{pH}$ are species-specific (Gao et al. 2016).

Long-time ( $2 \mathrm{~h}$ ) treatment of low $\mathrm{pH}$ (3.5) could destroy the photosynthetic activity of $U$. prolifera in this study (Fig. 2). The reason might be that the low $\mathrm{pH}$ impaired the membrane electrochemical potential and enzyme activity
(Milligan et al. 2009) and further damaged the PSII of $U$. prolifera. Salinity may affect the osmotic balance and electrochemical gradient of plant cells by changing the osmotic pressure of seawater (Gacia et al. 2007). Besides, salinity also affects nutrient uptake, chloroplast structure, and photosynthetic oxygen evolution (Pancha et al. 2015), playing a decisive role in macroalgae growth (Gustavs et al. 2009), reproduction, and photosynthesis (Mantri et al. 2011). However, can salinity and $\mathrm{pH}$ affect interactively 
the photosynthetic activity of $U$. prolifera? According to $R M-A N O V A$ statistics, $\mathrm{pH}$, salinity, and treatment duration showed an interactive impact on $\mathrm{F}_{\mathrm{v}} / \mathrm{F}_{\mathrm{m}}$ and $\Phi_{\text {PSII }}$ (Table 1). The order of the contribution to the variability of $F_{v} / F_{m}$ and $\Phi_{\text {PSII }}$ (Table 1) as indicated by $\eta^{2}$ was $\mathrm{pH}>$ salinity, indicating that the impact of $\mathrm{pH}$ on the photosynthetic activity of $U$. prolifera was greater than that of salinity.

In this study, NPQ at $\mathrm{pH} 3.5$ was higher than that of CK (Fig. 4A), which is consistent with the result of Liu et al. (2020) that NPQ of $U$. prolifera was markedly higher at $\mathrm{pH} 4$ than that of control. The thermal dissipation of light energy, referred to as NPQ, is the fastest and most flexible response towards excess light among the known photoprotection mechanisms (Goss and Lepetit 2015). The NPQ mechanism has been widely found in various plants, such as algae, mosses, and vascular plants (Gerotto et al. 2011). Under a moderate light intensity, the production of NPQ was related to the proton gradient $(\Delta \mathrm{pH})$ in vivo and in vitro of the thylakoid, which could reduce the pressure of electron transport and avoid the damage caused by reactive oxygen species (ROS) to cells (Peers et al. 2009). The green algae could express PsbS and LhcSR proteins, by which NPQ could be induced (Peers et al. 2009). PsbS, a Chl-binding protein in PSII, can sense the intrathylakoid lumen $\mathrm{pH}$ and is crucial for NPQ (Li et al. 2000).

LhcSR is a light-induced transcript (Gagné and Guertin 1992), which accumulates under environmental conditions known to induce photooxidative stress, including deprivation of carbon dioxide (Miura et al. 2004), sulphur (Zhang et al. 2004), or iron (Naumann et al. 2007), as well as high light (Ledford et al. 2004). Peers et al. (2009) found that the accumulation of LhcSR proteins was induced by high light and correlated with energy-dependent quenching $\left(\mathrm{q}_{\mathrm{E}}\right)$ capacity in Chlamydomonas. The $\mathrm{q}_{\mathrm{E}}$ type quenching represents, under most light conditions, the main constituent of NPQ. It is the fastest in terms of induction and relaxation (Derks et al. 2015). In addition, NPQ can prevent photochemical overexcitation in a xanthophyll cycle (Baker 2008). When the lumen pH drops to about 5 , the violaxanthin de-epoxidase (VDE) gene, a key gene in the xanthophyll cycle, can be activated to produce zeaxanthin to regulate the xanthophyll cycle and induce $\mathrm{q}_{\mathrm{E}}$ (Mozzo et al. 2008). However, in Bryopsidales, a monophyletic branch of the Ulvophyceae (Leliaert et al. 2012), the short-term inducible NPQ is neither related to a $\mathrm{pH}$-dependent mechanism, nor modulated by the activity of the xanthophyll cycle, even when the xanthophyll cycle is triggered under high light growth conditions, as seen in Caulerpa (Christa et al. 2017). Therefore, whether the increase of NPQ depends on $\mathrm{pH}$ and whether it is related to the xanthophyll cycle still needs further research.

In addition, we found that NPQ under low salinities (S 1 and S 10) was lower than that under high salinity (S 30) at a low pH (3.5) (Fig. 4B). Probably, the low salinity weakened the photoprotection induced by the low $\mathrm{pH}$ (3.5) and lost the ability to dissipate excess energy timely, resulting in the damage to the photosynthetic activity of $U$. prolifera. Why did the low salinity reduce the degree of photoprotection induced by low $\mathrm{pH}$ on $U$. prolifera? When $U$. prolifera was in a low-salinity environment, it absorbed water to balance the osmotic pressure, destroying cytomembrane and chloroplast membrane structures (Pancha et al. 2015), and further damaged the photoprotection mechanism. Meanwhile, to adapt to the low-salinity environment, the thalli might voluntarily lose some ions and soluble cellular components to reduce their osmotic pressure (Feng et al. 2016) at the expense of the destruction of their photosynthetic ability. In addition, the capacity of photoprotection declined with the increase of treatment duration (Fig. 5). Li et al. (2017) confirmed that long-time acid treatment harmed the photoprotection to $U$. prolifera, thus reducing the ability to self-regulate the xanthophyll cycle, which led to NPQ decline. Therefore, we speculated that if the $\mathrm{pH}$ of acid rain was $\leq 3.5$, with the salinity decrease (salinity $1 \%$ and $10 \%$ ) and the rainfall time increase ( 1 and $2 \mathrm{~h}$ ), the photosynthetic activity of $U$. prolifera would be destroyed and the scale of green tides would decrease.

Conclusion: The impact of $\mathrm{pH}$ on the photosynthetic activity of $U$. prolifera was greater than that of salinity; the photosynthetic activity of $U$. prolifera treated under $2-\mathrm{h}$ treatment duration with the low $\mathrm{pH}$ (3.5) could not recover to normal levels after 24 -h recovering in natural seawater. Moreover, low salinity (salinity $1 \%$ and $10 \%$ ) reduced the degree of photoprotection under low $\mathrm{pH}$ (3.5) conditions, thereby impairing the photosynthetic activity. Finally, we speculated that if the $\mathrm{pH}$ of acid rain $\leq 3.5$, with the salinity decrease (salinity $1 \%$ and $10 \%$ ) and the rainfall time increase ( $1 \mathrm{~h}$ and $2 \mathrm{~h}$ ), the amount of $U$. prolifera and the scale of green tides would decrease.

\section{References}

Allakhverdiev S.I., Nishiyama Y, Miyairi S. et al.: Salt stress inhibits the repair of photodamaged photosystem II by suppressing the transcription and translation of $p s b A$ genes in Synechocystis. - Plant Physiol. 130: 1443-1453, 2002.

Bisson M.A., Kirst G.O.: Osmotic adaption in the marine alga Griffithsia monilis (Rhodophyceae): the role of ions and organic compounds. - Aust. J. Plant Physiol. 6: 523-538, 1979.

Baker N.R.: Chlorophyll fluorescence: a probe of photosynthesis in vivo. - Annu. Rev. Plant Biol. 59: 89-113, 2008.

Charlson R.J., Rodhe H.: Factors controlling the acidity of natural rainwater. - Nature 295: 683-685, 1982.

Chen B.B., Zou D.H.: Altered seawater salinity levels affected growth and photosynthesis of Ulva fasciata (Ulvales, Chlorophyta) germlings. - Acta Oceanol. Sin. 34: 108-113, 2015.

Christa G., Cruz S., Jahns P. et al.: Photoprotection in a monophyletic branch of chlorophyte algae is independent of energy-dependent quenching (qE). - New Phytol. 214: 11321144, 2017

Debnath B., Irshad M., Mitra S. et al.: Acid rain deposition modulates photosynthesis, enzymatic and non-enzymatic antioxidant activities in tomato. - Int. J. Environ. Res. 12: 203-214, 2018.

Derks A., Schaven K., Bruce D.: Diverse mechanisms for photoprotection in photosynthesis. Dynamic regulation of photosystem II excitation in response to rapid environmental change. - BBA-Bioenergetics 1847: 468-485, 2015.

Ding H.M., Yao F.F., Chen J.J. et al.: [Chemical characteristics 
of acidic precipitation in Tiantong, Zhejiang Province.] - Acta Scien. Circum. 32: 2245-2252, 2012. [In Chinese]

Feng C., Ding H.C., Yan X.H.: [Transcriptomic profiling of Pyropia haitanensis blade in responding to low-salinity stress.] - J. Fisheries China 40: 1842-1849, 2016. [In Chinese]

Gacia E., Invers O., Manzanera M. et al.: Impact of the brine from a desalination plant on a shallow seagrass (Posidonia oceanica) meadow. - Estuar. Coast. Shelf Sci. 72: 579-590, 2007.

Gagné G., Guertin M.: The early genetic response to light in the green unicellular alga Chlamydomonas eugametos grown under light dark cycles involves genes that represent direct responses to light and photosynthesis. - Plant Mol. Biol. 18: 429-445, 1992.

Gao S., Chen X.Y., Yi Q.Q. et al.: A strategy for the proliferation of Ulva prolifera, main causative species of green tides, with formation of sporangia by fragmentation. - PLoS ONE 5: e8571, 2010

Gao S., Sun Q.H., Tao Y.L. et al.: A decline in macro-algae species resulting in the overwhelming prevalence of Corallina species is caused by low-pH seawater induced by short-term acid rain. - J. Exp. Mar. Biol. Ecol. 475: 144-153, 2016.

Gerotto C., Alboresi A., Giacometti G.M. et al.: Role of PSBS and LHCSR in Physcomitrella patens acclimation to high light and low temperature. - Plant Cell Environ. 34: 922-932, 2011.

Gómez I., López-Figueroa F., Ulloa N. et al.: Patterns of photosynthesis in 18 species of intertidal macroalgae from southern Chile. - Mar. Ecol. Prog. Ser. 270: 103-116, 2004.

Goss R., Lepetit B.: Biodiversity of NPQ. - J. Plant. Physiol. 172: 13-32, 2015.

Gustavs L., Schumann R., Eggert A., Karsten U.: In vivo growth fluorometry: accuracy and limits of microalgal growth rate measurements in ecophysiological investigations. - Aquat. Microb. Ecol. 55: 95-104, 2009.

Hu H., Hua W., Shen A. et al.: Photosynthetic rate and chlorophyll fluorescence of barley exposed to simulated acid rain. Environ. Sci. Pollut. R., 2021. (In press)

Ju S.M., Wang L.P., Chen J.Y. et al.: Effects of silicon on the growth, photosynthesis and chloroplast ultrastructure of Oryza sativa L. seedlings under acid rain stress. - Silicon 12: 655-664, 2020.

Karsten U.: Research note: salinity tolerance of Arctic kelps from Spitsbergen. - Phycol. Res. 55: 257-262, 2007.

Kita I., Sato T., Kase Y., Mitropoulos P.: Neutral rains at Athens, Greece: A natural safeguard against acidification of rains. Sci. Total Environ. 327: 285-294, 2004.

Kumar A., AbdElgawad H., Castellano I. et al.: Physiological and biochemical analyses shed light on the response of Sargassum vulgare to ocean acidification at different time scales. - Front. Plant Sci. 8: 570, 2017.

Larssen T., Lydersen E., Tang D. et al.: Acid rain in China. Environ. Sci. Technol. 40: 418-425, 2006.

Ledford H.K., Baroli I., Shin J.W. et al.: Comparative profiling of lipid-soluble antioxidants and transcripts reveals two phases of photo-oxidative stress in a xanthophyll-deficient mutant of Chlamydomonas reinhardtii. - Mol. Genet. Genomics 272: 470-479, 2004

Leliaert F., Smith D.R., Moreau H. et al.: Phylogeny and molecular evolution of the green algae. - Crit. Rev. Plant Sci. 31: 1-46, 2012.

Levin L.A., Liu K.-K., Emeis K.-C. et al.: Comparative biogeochemistry-ecosystem-human interaction on dynamic continental margins. - J. Mar. Syst. 141: 3-17, 2015.

Li X.P., Björkman O., Shih C. et al.: A pigment-binding protein essential for regulation of photosynthetic light harvesting. -
Nature 403: 391-395, 2000.

Li Y.H., Wang D., Xu X.T. et al.: Physiological responses of a green algae (Ulva prolifera) exposed to simulated acid rain and decreased salinity. - Photosynthetica 55: 623-629, 2017.

Liu M.X., Huang X., Song Y. et al.: Ammonia emission control in China would mitigate haze pollution and nitrogen deposition, but worsen acid rain. - P. Natl. Acad. Sci. USA 116: 7760$7765,2019$.

Liu T.W., Chen J., Wang W.H. et al.: A combined proteomic and transcriptomic analysis on sulfur metabolism pathways of Arabidopsis thaliana under simulated acid rain. - PLoS ONE 9: e90120, 2014.

Liu X.H., Huan L., Gu W.H. et al.: Acid treatment combined with high light leads to increased removal efficiency of Ulva prolifera. - Algal Res. 45: 101745, 2020.

Ma J., Wang W., Liu X.Y. et al.: Zinc toxicity alters the photosynthetic response of red alga Pyropia yezoensis to ocean acidification. - Environ. Sci. Pollut. R. 27: 3202-3212, 2020.

Mantri V.A., Singh R.P., Bijo A.J. et al.: Differential response of varying salinity and temperature on zoospore induction, regeneration and daily growth rate in Ulva fasciata (Chlorophyta, Ulvales). - J. Appl. Phycol. 23: 243-250, 2011.

Milligan A.J., Mioni C.E., Morel F.M.M.: Response of cell surface $\mathrm{pH}$ to $\mathrm{pCO}_{2}$ and iron limitation in the marine diatom Thalassiosira weissflogii. - Mar. Chem. 114: 31-36, 2009.

Miura K., Yamano T., Yoshioka S. et al.: Expression profilingbased identification of $\mathrm{CO}_{2}$-responsive genes regulated by CCM1 controlling a carbon-concentrating mechanism in Chlamydomonas reinhardtii. - Plant Physiol. 135: 15951607, 2004.

Mozzo M., Dall'Osto L., Hienerwadel R. et al.: Photoprotection in the antenna complexes of photosystem II role of individual xanthophylls in chlorophyll triplet quenching. - J. Biol. Chem. 283: 6184-6192, 2008.

Mubarakshina M., Khorobrykh S., Ivanov B.: Oxygen reduction in chloroplast thylakoids results in production of hydrogen peroxide inside the membrane. - BBA-Bioenergetics 1757: 1496-1503, 2006.

Naumann B., Busch A., Allmer J. et al.: Comparative quantitative proteomics to investigate the remodeling of bioenergetic pathways under iron deficiency in Chlamydomonas reinhardtii. - Proteomics 7: 3964-3979, 2007.

Pancha I., Chokshi K., Maurya R. et al.: Salinity induced oxidative stress enhanced biofuel production potential of microalgae Scenedesmus sp. CCNM 1077. - Bioresource Technol. 189: 341-348, 2015.

Peers G., Truong T.B., Ostendorf E. et al.: An ancient lightharvesting protein is critical for the regulation of algal photosynthesis. - Nature 462: 518-521, 2009.

Polishchuk O.V., Vodka M.V., Belyavskaya N.A. et al.: The effect of acid rain on ultrastructure and functional parameters of photosynthetic apparatus in pea leaves. - Cell Tiss. Biol. 10: $250-257,2016$.

Raut R., Sharma S., Bajracharya R.M.: Biotic response to acidification of lakes - a review. - Kathmandu Univ. J. Sci. Eng. Technol. 8: 171-184, 2012.

Shukla J.B., Sundar S., Shivangi, Naresh R.: Modeling and analysis of the acid rain formation due to precipitation and its effect on plant species. - Nat. Resour. Model. 26: 53-65, 2013.

Singh A., Agrawal M.: Acid rain and its ecological consequences. - J. Environ. Biol. 29: 15-24, 2008.

Sun J.Z., Ning X.R., Le F.F. et al.: Long term changes of biodiversity of benthic macroalgae in the intertidal zone of the Nanji Islands. - Acta. Ecol. Sin. 30: 106-112, 2010.

Sun Z.G., Wang L.H., Chen M.M. et al.: Interactive effects of 
cadmium and acid rain on photosynthetic light reaction in soybean seedlings. - Ecotox. Environ. Safe. 79: 62-68, 2011.

Tang Y.B., Liao Y.B., Shou L. et al.: [Influence of coralline algae on biodiversity of macrobenthic community in intertidal zone of Nanji Islands.] - Biodiversity Sci. 22: 640-648, 2014. [In Chinese]

Xing J.W., Song J.M., Yuan H.M. et al.: [Chemical characteristics of acid rain under the representative interaction among sea, land and anthropogenic activities in the coastal area of Qingdao.] - Environ. Chem. 36: 296-308, 2017. [In Chinese]

Xu Y., Wang W.L., Xu K. et al.: [Effect of different saline stress on physiological indexes of Pyropia haitanensis.] - J. Appl. Oceanogr. 37: 380-386, 2018. [In Chinese]

Yabe T., Ishii Y., Amano Y. et al.: Green tide formed by freefloating Ulva spp. at Yatsu tidal flat, Japan. - Limnology 10: 239-245, 2009.

Yamochi S.: Effects of desiccation and salinity on the outbreak of a green tide of Ulva pertusa in a created salt marsh along the coast of Osaka Bay, Japan. - Estuar. Coast. Shelf Sci. 116: 21-28, 2013.

Yamori W., Takahashi S., Makino A. et al.: The roles of ATP synthase and the cytochrome $b_{6} / f$ complexes in limiting chloroplast electron transport and determining photosynthetic capacity. - Plant Physiol. 155: 956-962, 2011
Zhang C.Y., Yi C.Q., Gao X.Z. et al.: Physiological and biochemical responses of tea seedlings (Camellia sinensis) to simulated acid rain conditions. - Ecotox. Environ. Safe. 192: 110315,2020

Zhang M.Y., Wang S.J., Wu F.C. et al.: Chemical compositions of wet precipitation and anthropogenic influences at a developing urban site in southeastern China. - Atmos. Res. 84: 311-322, 2007a.

Zhang S.Y., Wang Z.H., Lin J. et al.: [Variation of fisheries resources in summer and autumn in seaweed beds of Gouqi Island.] - Mar. Fish Res. 28: 45-52, 2007b. [In Chinese]

Zhang Z.D., Shrager J., Jain M. et al.: Insights into the survival of Chlamydomonas reinhardtii during sulfur starvation based on microarray analysis of gene expression. - Eukaryot. Cell 3: 1331-1348, 2004.

Zheng H.B., Jiang X.M., Fu C.H. et al.: [Distribution characteristics of benthic algae in intertidal zone of Dongji of Zhejiang province.] - J. Ningbo Univ. 24: 29-35, 2011. [In Chinese]

Zhou S.J., Zhang M., Chen S.Z. et al.: Acid resistance of Masson pine (Pinus massoniana Lamb.) families and their root morphology and physiological response to simulated acid deposition. - Sci. Rep.-UK 10: 22066, 2020.

(C) The authors. This is an open access article distributed under the terms of the Creative Commons BY-NC-ND Licence. 